PLANTS PEOPLE

POSSIBILITIES

\title{
Blister Disease of Fruit Trees
}

\section{Author(s): G. Massee}

Source: Bulletin of Miscellaneous Information (Royal Botanic Gardens, Kew), Vol. 1915, No. 3 (1915), pp. 104-107

Published by: Springer on behalf of Royal Botanic Gardens, Kew

Stable URL: http://www.jstor.org/stable/4107514

Accessed: 27-06-2016 10:56 UTC

Your use of the JSTOR archive indicates your acceptance of the Terms \& Conditions of Use, available at

http://about.jstor.org/terms

JSTOR is a not-for-profit service that helps scholars, researchers, and students discover, use, and build upon a wide range of content in a trusted digital archive. We use information technology and tools to increase productivity and facilitate new forms of scholarship. For more information about JSTOR, please contact support@jstor.org.

Royal Botanic Gardens, Kew, Springer are collaborating with JSTOR to digitize, preserve and extend access to Bulletin of Miscellaneous Information (Royal Botanic Gardens, Kew) 
of the elements and the abundance of spores, and discrepancies occur in the various descriptions published, as to the presence of cystidia. Schrenk mentioned "blunt cystidia" projecting but little over the surface of the hymenium. Hedgcock and Long describe for $F$. juniperinus "cystidia few, nearly colourless, $100 \times 20 \mu$, pointed, somewhat encrusted," and for F. Earlei no cystidia, while Lloyd*, who examined part of the type specimen of $F$. juniperinus, states that no cystidia are present. In the specimens at Kew, the hymenium consists of young and mature basidia, the latter with 2-4 sterigmata, and between these are occasional sterile bodies of varying size (Text-fig. $b$ ). These are hyaline, very thin-walled, smooth, cylindrical or somewhat fusiform, projecting very little, $7 \mu$ wide and up to $25 \mu$ long. Without an examination of the type material, it is not possible to say whether these may be von Schrenk's cystidia. No large cystidia like those described by Hedgcock and Long are present.

The distribution of the fungus, as at present known, is peculiar. In the United States $F$. juniperinus has been recorded from Tennessee, Kentucky and Maryland, and F. Earlei from Texas, New Mexico, Arizona and Colorado. Lloyd thas recorded it from Russia, and has pointed out* that F. Demidoffi (Lév.) Sacc., described on Juniperus excelsa from Russia, was probably the same species. The new record from East $A$ frica gives a third widely separated locality. The fungus does not as yet appear to have been recorded from any other part of the world, and even where found, the sporophores seem to be as a rule but sparingly produced.

\section{XIII.-BLISTER DISEASE OF FRUIT TREES.}

\section{G. MASSEE.}

(With Plate.)

The blistering and cracking of the shoots and fruit of apple, pear and cherry trees is of common occurrence, and in many instances, more especially when the fruit is attacked, the injury is of a serious nature. The general superficial appearance of the disease resembles that of apple scab, caused by Venturia inaequalis, Aderh., and as such has up to the present been mistaken in this country, althongh what appears to be the same disease, has been described by Pole-Evansł and P. A. van der Bijlई as present on apple trees in South Africa. In this instance, however, the authors were only acquainted with one stage in the life-cycle of the fungus concerned, to which the5 applied the name Coniothecium chomatosporum, Corda.

Small blisters during July and August on the young shoots of the year is the first indication of the presence of the disease. Later in the season the skin or epidermis covering these blisters is ruptured, and a blackish-olive patch is exposed, which on microscopic examination

* Lloyd. Mycol. Notes, No. 38, 1912, p. 522.

† Lloyd. Letter No. 38, p. 10.

\$ Pole-Evans, I. B., Transvaal Agric. Journ., 5, p. 680 (1907).

$\S$ Bijl, Paul A. van der. S. African Agric. Journ., 8, p. 64 (1914). 
proves to consist of a tangled mass of olive-coloured mycelium, which gives origin to numerous clusters of various sizes, composed of very large, globose cells, each having two septa crossing at right angles. This condition of the fungus under consideration was at one time considered as an entity, and was known as Coriothecium chomatosporum, Corda. During the autumn and winter the dark-coloured mycelium, emerging through the ruptured blisters, spreads on the surface of the shoot, forming blackish-olive patches of varying extent. The mycelium of the fungus is confined to the cortex, which is killed down to the wood, and during the winter the branch dies. In the spring the masses of large cells of the Coniothecium give origin to myriads of small, elliptical, hyaline spores by a process of budding, and these minute spores are capable of infecting young apple shoots, and giving origin to the Coniothecium condition of the fungus, which is thus capable of reproducing itself indefinitely without the intervention of the two other stages of the fungus to be described, known respectively as Phoma mali, Schulz and Sacc., and Diaporthe ambigua, Nits., the latter being the ascigerous form. The l'homa and the Diaporthe are both pure saprophytes, appearing on the branches killed by the Coniothecium, which is the only parasitic form included in the life-cycle of the fungus.

The small, hyaline spores produced by budding from the large Coniothecium cells were placed on sterilised and uninjured young apple shoots, protected from outside infection by waterproof paper. After an interval of seven weeks, small blisters were present on the shoot, which, on microscopic examination, proved to be caused by the growth of masses or conglomerations of large Coniothecium cells. These masses continue to increase in size and press the epidermis upwards, at first forming a wart or blister; eventually the epidermis is ruptured. The blisters invariably first appeared close to the lenticel, which suggests that infection only occurs at these points, and that the budding spores cannot enter through the unbroken epidermis. In course of time, the mycelium spreads in the cortex, and blisters, due to clusters of cells, may appear at any point on the shoot. When budding spores are sown in a nutritive medium, the mycelium is at first colourless and very slender, and gradually passes through a pale olive to an almost opaque blackish-olive colour, and at the expiration of about six weeks, numerous conglomerations of large celis are present. The large cells commence budding at once. When petridish cultures of budding spores are about three months old, the Phoma stage of the fungus is produced in abundance. Phoma spores from such cultures, sown in a nutrient medium, gave origin, first to the Coniothecium condition and afterwards to the Phoma. Phoma spores from the same source, when placed on young apple shoots, gave origin to the Coniothecium condition of the fungus. In every experiment with Phoma spores, whether obtained from pure cultures or from the Phoma on shoots that had been killed the previous year by the Coniothecium, the first product of germination was the Coniothecium conilition, followed by the Phoma; hence it may be concluded that the infection of young shoots and fruit may also be due to the Phoma stage of the fungus present on dead shoots.

When the fruit is attacked, the effect produced depends to a great extent on the age at which infection occurs. On the young, hard fruit 
blisters are formed and the tissue is soon killed at the points of infection. This often results in the formation of cracks, which continue to increase in size as the apple grows. The general appearance in this case resembles that of apple scab. When the fruit is partly ripe, largo, brown, depressed patches are formed, the skin becomes black and parchment-like, and numerous masses of Coniothecium are produced in the tissue. At a later stage, the Phoma form of fruit bursts through the blackened skin. In the case of the fruit, infection takes place through the numerous minute ruptures of the skin which are perhaps imperfectly-formed lenticels.

Coniothecium has for some time been considered of doubtful generic value. In "British Fungus Flora" the following rider to the generic diagnosis occurs : "Conidia usually very variable, resembling conglomerations of cells of variable size. A very badly-defined genus, and it is doubtful whether many of the so-called species are such in reality." Mr. C. O. Farquharson was the first to demonstrate that Coniothecium resulted from the germination of Phoma spores, when working at a water-lily disease in the Jodrell laboratory, but the investigation was not completed owing to his departure for Southern Nigeria as mycologist. He also proved that the spores of Phoma abietis, Br., produced a Coniothecium stage on germination, hence, in future, Coniothecium will only be retained as a form-genus until its components are correlated with their respective Phoma forms.

The Phoma stage appears in great abundance in the spring on shoots and spurs killed by the Coniothecium the previous year. From other species of Phoma occurring on the same hosts, $P$. mali is readily distinguished by the form of the perithecium and the spores. The perithecium is very much vertically depressed, so that a section is irregularly biconvex. The spores are fusiform or spindle-shaped and measure 7-8 $\times 2-3 \mu$. Spores of the Phoma placed on sterilised apple shoots were found to enter the tissue only through the lenticels. On germination, a weft of very delicate hyaline mycelium surrounded the dead cells of the lenticel, and afterwards spread into the adjoining living tissue of the cortex, where they increased considerably in thickness and gradually assumed an olive-green colour, and gave origin to typical Coniothecium groups of cells. In all probability the mycelium first produced by the spores lives as a saprophyte, obtaining its food from the dead tissue of the lenticel, and afterwards assumes a parasitic habit. The parasitic phase is, however, not absolutely necessary, as when Phoma spores are sown in a nutrient medium the Coniothecium and Phoma stages are produced in due course. This, however, may not occur in nature, as $\Gamma$ have not succeeded in infecting dead shoots with either Coniothecium or Phoma spores.

The ascigerous form of fruit is rare, and, as in many other cases, would appear to play but an unimportant part in the continuation of the species, either as regards time or space. It occurs on dead twigs either along with the Phoma or at a later stage. I have only met with the ascigerous stage once- on dead apple twigs, accompanying the Phoma. The ascigerous spores sown on a nutrient medium produced a dense mass of colourless mycelium, which gave origin to the Phoma without the intervention of the Coniothecium; the latter, how-

* Massee, G., Brit. Fungus Flora, 3, p. 427 (1893). 
Kew Bulletin, 1915.]

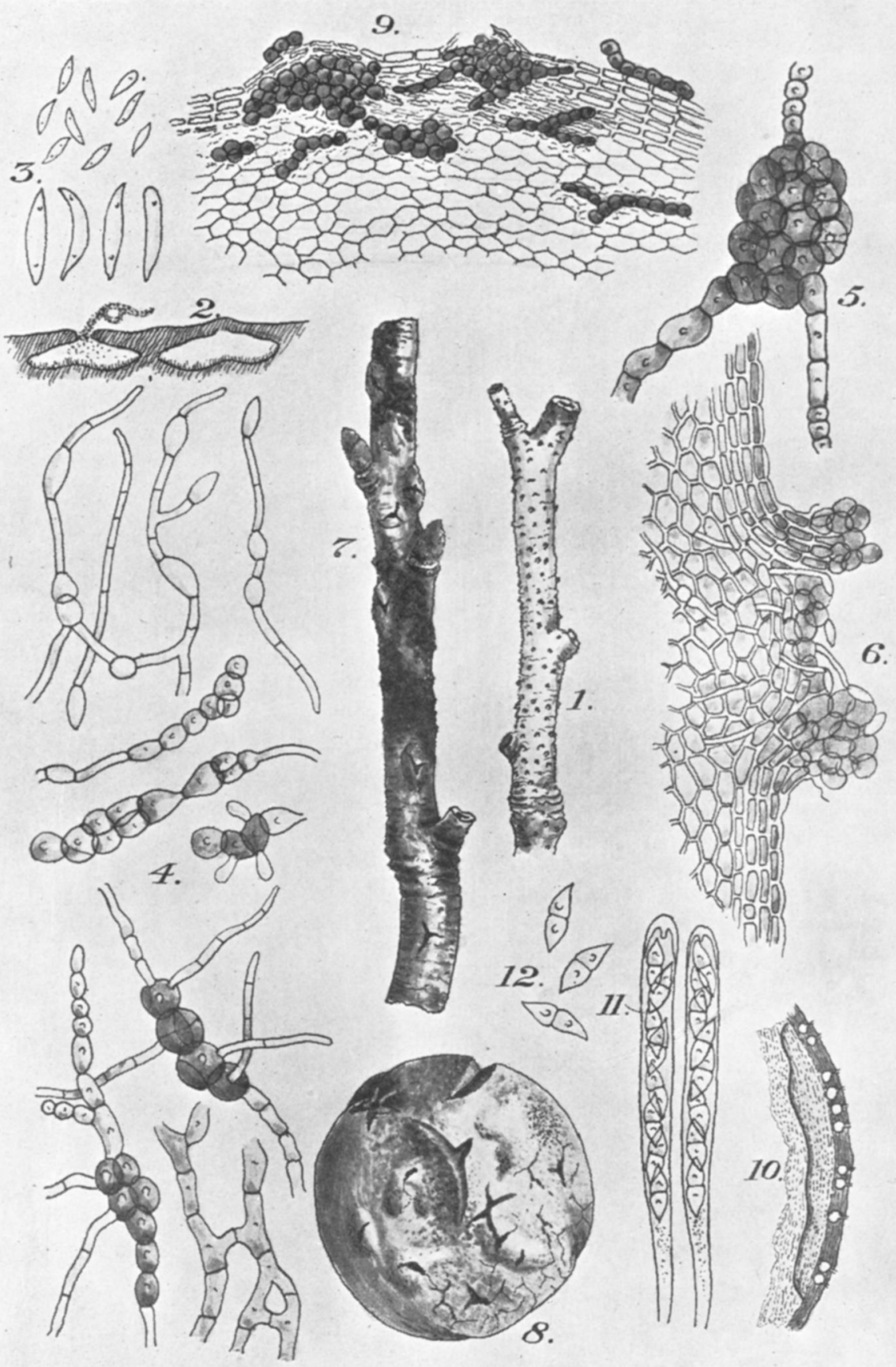

To face page 107.]

This content downloaded from 131.247.112.3 on Mon, 27 Jun 2016 10:56:47 UTC All use subject to http://about.jstor.org/terms 
ever, was formed as usual from the Phoma spores obtained from the germination of ascigerous spores.

As to preventive measures, probably spraying with Bordeaux mixture, if applied sufficiently often, would save young shoots and fruit from infection, but the process would have to be repeated every season. The most certain method for preventing infection would be to remove the dead twigs and spurs bearing the fungus.

\section{JEESCRIPTION OF THE FIGURES.}

1. Phoma stage of fungus on a dead apple twig. Nat. size.

2. Section of Phoma perithecia on apple shoot. Mag.

3. Phoma spores. Mag.

4. Various stages of germination of Phoma spores, and the production of the condition known as Coniothecium from the mycelium. Mag.

5. A more advanced condition of the Coniothecium stage. Mag.

6. Spores of the Phoma germinating on the surface of a lenticel of an apple twig. The mycelium is seen penetrating the tissue of the cortex. Mag.

7. Portion of an apple shoot showing the effect produced by the Coniothecium stage of the disease. Nat. size.

8. An apple showing the Coniothecium stage of the disease. Nat. size.

9. Section through the cortex of an apple twig, showing the Coniothecium in the tissues. Mag.

10. Section through the stroma and perithecia of Diaporthe ambigua, the ascigerous stage of the fungus. Mag.

11. Asci and spores of Diaporthe ambigua. Mag.

12. Free spores of Diaporthe ambigua. Mag.

\section{XIV.-SOME CHINESE MARINE ALGAE.}

A. D. Cotton.

Two packets of marine algae from Wei-hai-wei were recently presented to Kew by the Rev. H. Boyden, of Exeter. The material was collected by Mr. Boyden's son, Dr. P. Hamilton Boyden, surgeon in the Royal Navy, mainly during 1913, but some specimens bear the date October, 1910.

In the Journal of Botany for 1904 Mrs. Gepp reported on a collection from the same locality, also made by Dr. Boyden, and this is practically the only recent list-at all events in a European language-of marine algae from China. Some older papers, which include several Chinese records, are in existence, but, owing to the liberal views then held as to species, and to other reasons, these lists require thorough revision. The present collection differs decidedly from that examined by Mrs. Gepp, a fact which shows how the flora varies, and one which should be an encouragement to botanists and others who take the trouble to investigate the seaweed flora of these little-known shores. Though most valuable, the collections forwarded by Dr. Boyden can only be regarded as samples. The littoral flora doubtless varies, not only through the different months of the year, but also with the different types of habitat afforded by the coast-line. Further samples as opportunity offers would therefore be most welcome.

Much of the coast of northern China is unfavourable for a good seaweed flora. Owing to the presence of the great Hoang-ho, or 